\title{
The Unequal Burden of Income Poverty on Time Use in South Africa
}

\author{
BurÇA KizILIRMAK ${ }^{\mathrm{a}}$ EMEL MEMişb
}

Received: 13.05.2019; Revised: 05.10.2019; Accepted: 06.10.2019

This study aims to contribute to the research on poverty by analysing the association of income poverty with gender inequalities in time use patterns. Based on South Africa's first time-use data compiled in 2000, we explore whether household income poverty has any influence on the typical patterns of time use of women and men. Controlling for a variety of household and individual characteristics, we assess the extent to which living in income poverty produce long hours of work - in particular unpaid work hours- using bivariate and multivariate Tobit estimations. Our results show asymmetric impacts of income poverty on women's and men's time allocations controlling for the widely accepted determining factors. While women in poor households spend more time on unpaid work activities, we do not see any significant change in men's unpaid work time with poverty status. Women's total paid and unpaid work time is higher under poverty as the increase in their unpaid work time extends away from the decline in paid work time. Other findings obtained provide supporting evidence presented in previous research: being married/cohabiting with a partner has an increasing impact on women's unpaid work, whereas an opposite impact is observed for their male counterparts. Women's unpaid work time increases with the number of preschool children, whereas it is the paid work time which rises in case of men's work time.

JEL codes: D13, J16, J22, I32

Keywords: Unpaid work; Time use; Gender-based inequality; Poverty

\section{Introduction}

Widespread income poverty has been a major challenge in South Africa. While a large body of literature exists analysing the structural and chronic nature of poverty, the impact of poverty on time use inequalities remains largely unexplored. The onset of the 2007-2008 economic crisis on top of food price volatility has placed an even higher priority to the issue of combating poverty on the policy agenda. Poverty creates different forms of inequalities among different social groups and designing effective anti-poverty policies involves understanding their dynamics. The purpose of this paper is to address one such form of inequality for which there has been very limited discussion: that of time use inequalities.

a Corresponding author. Ankara University, Dept. of Economics, Ankara, Turkey (e-mail: burca@politics.ankara.edu.tr; abkizilirmak@gmail.com).

b Ankara University, Dept. of Economics, Ankara, Turkey \& Levy Economics Institute, NY, USA (e-mail: emel.memis@gmail.com ). 
The current study establishes that time use data tells an untold tale about the impacts of poverty on peoples' lives. Indeed, revealing the significance and the characteristics particularly of the non-market unpaid work, time use data can be utilised to explore the impacts of poverty on the unpaid sphere of the economy, which would not be observed otherwise. Time is one of the most important resources we have and inequalities in time-use provides important insights on how people experience poverty and help us better understand the social settings that people live in. An important objective of economic and social policymaking is to improve human life; as such, time use information stands at the heart of the research and discussions on peoples' well-being and distress even when conventional indicators present a positive picture (Gershuny, 2000). This becomes highly critical in times of crises like the recent period. Past economic crises have shown that along with the rise in joblessness and poverty, unpaid work becomes more widespread and intensified, particularly for women and children during economic crises (Milkman, 1976; Elson, 1993). The well-being of women and many children relies heavily on women's access to paid work and their earning capacity. This is more critical particularly for households with low income, as higher participation of women in the labour market, known as the 'added worker effect', is a major coping mechanism during downturns and crises in many countries (Skoufias, 1993; Connelly et al., 1996; ECLAC, 2007).

In fact, there is extensive literature focusing on the developing countries that establishes important links between gender inequalities in the labour market and poverty. Compared to their male counterparts, women are more prone to being in poverty and experience a greater depth of poverty with higher levels of unemployment, lower labour force participation, a higher probability of doing more informal work, and lower social security levels than men. Each of the factors feeding into poverty is closely related to the uneven gender-based unpaid work burden distribution. This inequality of work burden needs to be made an integral part of public policy design but has not yet gained enough attention from policymakers. Poverty, and the feminisation of poverty, both have complex economic, social, and cultural dimensions. Although time use surveys may not provide a complete multiperspective analysis capturing all of these dimensions, they nevertheless provide data on a large nationwide sample that can serve as an empirical reference point for investigating the relationship between poverty and time.

In this study, which is based on the nationwide time use survey data compiled in 2000 for South Africa, we explore the determinants of time spent on different paid work and unpaid work activities by South African women and men focusing on the impact of income poverty. Accordingly, we seek answers to the following questions: are there differences between women and men with respect to the relation between their poverty status and their time spent on unpaid and paid work? Are these differences observed for all types of unpaid work activities? Do the results vary among different residential settings?

In order to estimate the determinants of time use, we estimated bivariate and multivariate Tobit models. The bivariate Tobit model involves paid and unpaid work time as dependent variables. In the multivariate Tobit model, the unpaid work time variables are modelled at a more disaggregated level, resulting in four dependent variables: water and fuel collection, social care, home maintenance; and paid work. Results obtained provide evidence for the unequal burden of poverty on time use patterns. Controlling for the factors that potentially influence both poverty and time use patterns, we find that being poor increases women's unpaid work time, while no significant change is obtained in the case of men. In addition 
to this main result, we also find that while the characteristics associated with being poor increases women's total work burden, for men, the work burden declines.

A prerequisite in effective policymaking for poverty alleviation is healthy targeting (i.e., detecting the groups who are facing more of the burden of poverty), and our results point to issues that have not been paid proper attention to and that might require policy intervention. Our findings point to policy implications for developing strategies and programs to eradicate poverty and promote gender equality in South Africa. The remainder of this paper is organised as follows. The next section reviews the literature. The third section describes the data we use and poverty in South Africa. In the fourth and fifth sections, we present the methodology we use in our empirical analysis and estimation results respectively. The last section concludes the paper.

\section{Literature Review}

Income poverty is likely to have two conflicting effects on an individual's time allocation. On the one hand, members of households living in poverty are urged to spend more time on paid work, thus leaving them less time for unpaid work at home. On the other hand, poor people may have to spend longer time on unpaid work activities as they lack the income to buy the necessary services and appliances. Which of these effects is stronger depends particularly on gender through which intra-household power relations work. Thus, at the outset, it is possible to argue that the links between poverty and intra-household allocation of time are conditional on the existing structure of the division of work time among household members. In addition, there is a reverse causality between the unequal outcomes in the market and gender inequalities in the household division of labour: Inequality in the household feeds back to the former inequality in the market, a phenomenon called 'housework penalty' (Hersch \& Stratton, 1997; Bryan \& Sevilla-Sanz, 2011).

Data collected by time use surveys have established that across the world, while men's work is highly associated with paid market work, women devote a majority of their work time to doing unpaid work (Gershuny, 2000; Beneria, 2003). ${ }^{1}$ Gender differences in the allocation of time between paid and unpaid work have important implications in terms of well-being (Floro, 1995; Antonopoulos \& Hirway, 2010; Elson, 2005). Increased segregation of unpaid work and paid work by gender push, particularly women into social and income poverty (Elson, 2009) as well as time poverty (Bittman \& Folbre, 2004; Memiş \& Antonopoulos, 2010). What determines this allocation of time would also be relevant for its relation to poverty.

Although empirical evidence points to the traditional division of labour, there is no consensus in the theoretical literature on a model that explains this fact. While some studies are based on Becker (1981)'s full specialisation household model with a rational choice perspective (Gronau, 1973), others, based on institutions, underline the relation between institutional structures and the decision-making processes of individuals (Hartmann, 1979). These studies argue that individual choices are not free from social norms, regulations, laws, and also policies (Bittman et al., 2003). Empirical investigations also show that significant

\footnotetext{
${ }^{1}$ Unpaid work covers a range of different activities from taking care of children and other household members in need of cleaning, shopping, maintaining the house, doing volunteer work, and helping other members in the community. In some developing countries, in areas where services are lacking, unpaid work includes activities such as the collection of free goods like water and fuel from common lands vital for the household.
} 
differences exist between women and men and are persistent. Accordingly, any change in a national context is considered to have a direct impact on decisions, while also indirectly influencing the normative context in which the decision is embedded (Hook, 2010).

When it comes to the analysis of poverty, conventional measures of poverty take the household as the unit of analysis and assume that resources are equally shared within a household. Yet many studies on poverty and intrahousehold allocation of resources have pointed to the inequalities in access to resources and/or the sharing of the burden of poverty (Sen, 1984; Haddad \& Kanbur, 1990; Harris, 1990). One of the earliest works on gender with relevance for poverty analysis came from the United Nations Decade for Women (1975-1985), which questioned the assumption of a unitary household operating on altruistic principles, both in the analysis as well as its use as an appropriate target for poverty alleviation. The research that followed introduced the well-known concept of the 'feminisation of poverty', which is the empirical expression of the fact that women, compared to men, in general, have a higher incidence of income poverty and that women's poverty is more severe than men's (Çağatay, 1998). A gendered perspective has contributed substantially to the measurement of poverty by challenging the one-dimensional conceptualisation of poverty and raising questions about poverty targeting in policy circles.

The discussions on poverty and time use go back to the late 1970s and generally focus on advanced country case studies. Vickery (1977)'s empirical work presents the time poverty situation in the United States and points to the need for analysing time use patterns of individuals in understanding poverty. ${ }^{2}$ Following Vickery's pioneering work, in a more recent study on the US, Duncan et al. (2001) compare families receiving Aid to Families with Dependent Children (AFDC) with other families in terms of their time use, among other characteristics. ${ }^{3}$ Another study on the time use of poor women in the US is carried out by Cash et al. (2005) and investigates not only women receiving public assistance but also women living in poverty in general. ${ }^{4}$

Until recently, the empirical literature on the impact of poverty on time use in developing countries was very limited. Hirway (2010) explored the relation between time use and poverty using Indian time use data and found the intrahousehold division of work to be a significant dimension in understanding poverty. She also showed a negative correlation between the unpaid workload of women and income level where ultra-poor women have the highest burden of total work. Memiş \& Antonopoulos (2010) discuss and present the close links between poverty and inequalities in time use patterns focusing on the aggregate sum of unpaid work time of women and men in South Africa. The evidence they provide shows that the gap between women and men increases as household income deteriorates.

\footnotetext{
${ }^{2}$ See Harvey \& Mukhopadhyay (2007) for the Canadian case while Burchardt (2008) presents a study for the UK.

${ }^{3}$ Using the Panel Study of Income Dynamics (1971-72) and National Study of Families and Households (1990-94) data, they conclude that non-working single mothers receiving AFDC do more housework than working single mothers and working mothers in two-parent households of high socioeconomic status. Low socioeconomic status working mothers and high socioeconomic status non-working mothers, both in twoparent families, are found to be doing more housework than the non-working single mothers receiving AFDC. In terms of housework and child-related activities, they find no differences among the women investigated.

${ }^{4}$ Using the 1994 National Study of Families and Households, they find that women who are poor spend significantly more time on household work.
} 


\section{Profile of Income Poverty in South Africa}

The data we use in this study comes from the South Africa Time Use Survey that was conducted in 2000 (SA-TUS 2000). ${ }^{5}$ The survey was conducted in three rounds (tranches) in order to capture potential seasonal variations in time use. These rounds were carried out in February, June and October of 2000. The sample covered all nine of South Africa's provinces (see Table 2), and within each province, four different settlement types were covered, these being: formal urban, informal urban, rural commercial farms and other rural settlements.

Formal urban residential areas include traditional residential suburban areas and city or town centres, and those residing within these areas are typically middle income or wealthy households. Informal areas, on the other hand, include shantytowns and slums. Rural households are divided into households living in areas demarcated as commercial farms or rural areas where commercial activities (such as mining) take place. As such 'rural commercial' households are not necessarily themselves involved in agricultural or mining activities. However, they are very often involved in these activities, sometimes directly and sometimes indirectly. The remainder of rural areas basically makes up what was formerly known as the homelands or Bantustans in South Africa. During the 1960s and 1970s the South African government, as part of their Apartheid policy, set aside various areas known as homelands. The homelands were reserved for Africans of specific ethnic groups, depending on the geographic positioning and dominant ethnic group of the region. Today the majority of the population in the former homelands are still African.

SA-TUS 2000 consists of two sections. The first section involves a household questionnaire with many of the standard questions used in the Statistics South Africa (Stats SA) household surveys. This first section allows for comparison with the other surveys. One member per household was required to provide basic information about the household characteristics as a whole. In the second section, two people, aged ten years or above, from each household, were selected and questioned about the activities they had performed the previous day. Each respondent was also required to provide basic demographic information about themselves, such as their age, gender, race, education level and work status. The activities performed by each respondent were recorded in a twenty-four-hour diary divided into half-hour slots. In each time slot, at most three activities could be recorded.

SA-TUS 2000 differs from that of many other countries because, although it allows for three activities to be recorded per half hour, it does not ask respondents to distinguish between primary, secondary and tertiary activities. The activities performed in each time slot are given equal importance. Note that the approach where respondents are asked to prioritize activities is problematic for a number of reasons. It has been shown that there is a systematic bias in what activities are prioritized by respondents and secondly because analysts are prone to disregard all but the primary activity. Specifically, activities such as childcare are usually given a lower priority than other simultaneous activities and not reported as primary activities. For example, Valeria Esquivel has reported that the estimate of the time spent daily by women in Argentina (Buenos Aires) on childcare and care of adults increased by over thirty per cent, from fifty-eight to seventy-six minutes per day, when secondary activities were taken into account (Esquivel, 2010, 194-5).

\footnotetext{
${ }^{5}$ SA-TUS 2000 was the only time use dataset available online at the time our research started.
} 
SA-TUS 2000 provided for both simultaneous (i.e., those performed at the same time) and sequential (i.e. those performed one after the other within the time slot) activities. SA-TUS 2000 used two different methods to assign minutes to activities in the time use survey. Where only one activity was performed in a particular time slot, this activity was allocated thirty minutes. Where two activities were performed sequentially in a particular time slot, each activity was assigned fifteen minutes. Similarly, when a time slot consisted of three activities performed sequentially, each activity was allocated ten minutes. This method, which is called 'the total minutes' approach, ensures that the total minutes spent per person per day on all activities sums to twenty-four hours. ${ }^{6}$

The planned sample for the survey was 3,600 households per tranche, resulting in 10,800 households in total. However, the realized sample was smaller than planned at 8,564 households and 14,553 respondents of which 11,277 respondents, 5,249 men and 6,028 women, correspond to the working-age group who are sixteen years of age or older. Most of the households in the sample live in formal urban areas (42.2 per cent), followed by households living in informal urban areas (23.8 per cent). The rest of the population is settled in rural areas, either in commercial or ex-homeland areas (19.2 per cent and 14.8 per cent respectively).

Research on poverty in South Africa points to widespread poverty and deep inequalities between various population groups and regions. Using Income and Expenditure Survey and Labour Force Survey and applying the lower bound of a 'cost-of basic-needs' poverty line, Hoogeveen \& Özler (2006) calculate the poverty rate as approximately sixty per cent in 2000. Overall, the statistics indicate that poverty is more pronounced for Africans, female-headed households, inhabitants of rural areas and regions including Kwa-Zulu Natal, Limpopo and Eastern Cape provinces (Klasen, 1997; Woolard \& Leibbrandt, 1999; Aliber, 2003; Hoogeveen \& Özler, 2006; Leibbrandt et al., 2006; Armstrong et al., 2008). ${ }^{7}$

The extent and the structure of poverty according to the SA-TUS-2000 survey, in general, confirm the above-mentioned evidence. To derive a profile of income poverty in South Africa, we first grouped the households according to their poverty status, which is determined by comparing their household income level with the income poverty line (i.e., the Bureau of Market Research's Minimum Living Level). SA-TUS 2000 contains only one categorical variable on the usual monthly income of the household. Respondents were asked to indicate their monthly income based on a range of ten values, and for the purposes of this study, the midpoint value for each category was allocated as the actual monthly income per household. ${ }^{8}$ Mid-point levels obtained were compared with the income poverty line (Table $1)$.

6 Different than total minutes approach, data compiled based on total duration time of the activity do not usually add up to twenty-four hours per day for each individual. In the duration time approach, if an individual spends 30 minutes for activity A and activity B simultaneously, as the time for each activity is recorded as 30 minutes, and the total of all the activities in a day when added could be more than 24 hours. 7 See Aliber (2003) among others for historical background and socio-economic policies related to poverty and van der Berg et al. (2006) for a review of literature on the change in poverty rates in time in South Africa.

${ }^{8}$ In SA-TUS 2000 household income categories were as follows (with midpoint shown in brackets): R0 - R399 (R200); R400 - R799 (R600); R800 - R1,199 (R1,000); R1,200 - R1,799 (R1,500); R1,800 R2,499 (R2,150); R2,500 - R4,999 (R3,750); R5,000 - R9,999 (R7,500); R10,000 or more (R15,000); Don't know; Refusal. 
Table 1: Poverty level of income by household size

\begin{tabular}{|c|c|c|c|c|c|}
\hline \multirow{2}{*}{$\begin{array}{l}\text { Household } \\
\text { Size }\end{array}$} & \multirow{2}{*}{$\begin{array}{l}\text { Rand per } \\
\text { month* }\end{array}$} & \multirow{2}{*}{$\begin{array}{l}\text { Poverty } \\
\text { Rate** }\end{array}$} & \multicolumn{3}{|c|}{$\begin{array}{c}\text { Number of Employed Household } \\
\text { Members** }\end{array}$} \\
\hline & & & No & One & Dual \\
\hline & & & $\begin{array}{c}\text { employed } \\
55.7\end{array}$ & $\begin{array}{c}\text { Employed } \\
27\end{array}$ & Employed \\
\hline 2 & 773 & 46.9 & 68.3 & 44.2 & 37 \\
\hline 3 & 1,028 & 56.8 & 72.2 & 55.2 & 47.6 \\
\hline 4 & 1,290 & 53 & $82.8^{i i}$ & $65.3^{i i}$ & $56.9^{i i}$ \\
\hline 5 & 1,541 & 71.5 & & & \\
\hline 6 & 1,806 & 73.8 & & & \\
\hline 7 & 2,054 & 80.5 & & & \\
\hline 8 & $2,503^{i}$ & 86.5 & & & \\
\hline 9 & & 82.5 & & & \\
\hline 10 & & 85.8 & & & \\
\hline $10+$ & & 94.2 & & & \\
\hline Total & & 59 & & & \\
\hline $\begin{array}{l}\text { Source: * SAR } \\
\text { income povert } \\
\text { ranges. } \\
* * \text { Authors' ca } \\
i \text { corresponds }\end{array}$ & $\begin{array}{l}\text { N (2004). For } \\
\text { hresholds wit } \\
\text { ulation using } \\
\text { the househol }\end{array}$ & $\begin{array}{l}\text { householc } \\
\text { househol } \\
2000 \\
\text { h membe }\end{array}$ & $\begin{array}{l}\text { compared } t \\
\text { come level } \mathrm{r} \\
\text { ght and mor }\end{array}$ & $\begin{array}{l}\text { oousehold si } \\
\text { ed by ten } \mathrm{c}\end{array}$ & $\begin{array}{l}\text { eecific levels } \\
\text { ries of incom }\end{array}$ \\
\hline
\end{tabular}

There is a large variation in income poverty rates across provinces. Large parts of what is today the Eastern Cape Province contain the former homelands of Ciskei and Transkei. Similarly, large parts of KwaZulu-Natal Province formerly made up the KwaZulu tribal areas. Large areas in the northwestern, northern and northeastern parts of South Africa, which today forms the North West, Limpopo and Mpumalanga provinces, also formerly consisted of homelands. A comparison of household poverty across these provinces reveals that poverty incidence is highest in these provinces (Table 2). When using our categoriza-

Table 2: Provincial poverty rates (per cent)

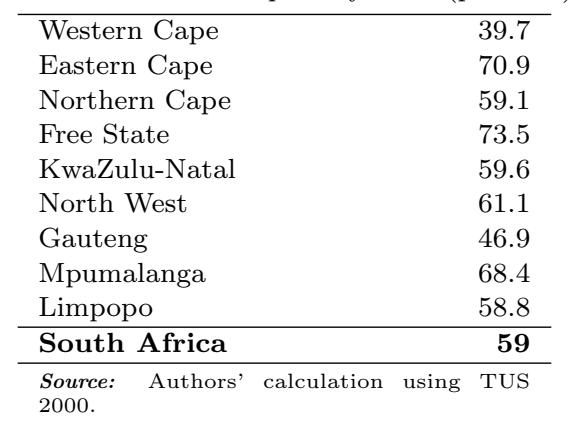

tion of residential areas, poverty rates again reveal a deep divide among urban/rural and ex-homelands. While forty-two per cent of the people living in urban formal is living in poverty, this figure is as high as 82.3 per cent in ex-homeland areas (Table 3). Population-wise, the majority of South Africans who live in poverty reside in urban areas (30.1 per cent in urban formal and 29 per cent in informal areas adding up to almost 60 per cent in total) (Table 3).

The poverty profile of South Africa shows evidence for its gender dimensions and child poverty. Among the total poor population, 56.3 per cent are women. In addition, more 
Table 3: Poverty rates by area of residence

\begin{tabular}{lcc}
\hline Residential Area & $\begin{array}{c}\text { Poverty Rate } \\
\text { (per cent) }\end{array}$ & $\begin{array}{c}\text { Distribution of } \\
\text { Poor People }\end{array}$ \\
\hline Urban formal & 42 & 30.1 \\
Urban informal & 71.8 & 29 \\
Rural ex-homeland & 82.3 & 20.6 \\
Rural commercial & 62.6 & 20.3 \\
\hline Total & $\mathbf{5 9}$ & $\mathbf{1 0 0}$ \\
\hline Source: Authors' calculation using TUS 2000.
\end{tabular}

women are poor compared to men: 62.2 per cent of women are poor, whereas, for men, 55.4 per cent of them are poor. As expected, poor households tend to be larger (Table 1) and poverty rates constantly rise with the number of children: while 57.1 per cent of the people who have no children aged younger than five are poor; all of the people who have four and five children within the same age range are income poor. In a similar manner, all the households with more than six children aged between six and seventeen years old are income poor as well.

With respect to the employment status of household members, poverty rates decline with the number of employed living in the household (Table 1). However, among the households with four or more members, despite the fact that two of the members are employed, more than half are still living under poverty. We also observe an association between poverty and unemployment in South Africa. When we categorize South Africans according to their employment status, we see that 76.3 per cent of unemployed people is poor. However, surprisingly, many people are poor even though they have jobs to do: among the employed, the proportion of poor people corresponds to 50.8 per cent. Among the poor and employed, we observe that fifty-six per cent report that their primary source of income is wages/salaries. This raises a serious issue on the one hand with regards to the sufficiency of wage levels in South Africa and on the other as a reflection of high dependency ratios among households given such high rates of unemployment.

The living conditions of households provide additional information on income poverty in South Africa. Of all the households in the sample, only 53.3 per cent live in house or brick structures on a separate stand. Only 35.4 per cent have piped water in the dwelling, and 30 per cent have piped water on site. Availability of electricity seems to be rather widespread: 68.4 per cent use electricity for lighting, heating or cooking. Use of machines at home is also prevalent to some extent: 63.6 per cent of the families have at least one washing machine, vacuum cleaner, refrigerator or stove.

Adults in the sample have 7.8 years of schooling on average, approximately equal for women and men. Majority of the adults are wage or salary earners (36.2 per cent of the women and 48.3 per cent of the men). This is followed by people with no personal income (25.6 per cent of the women and 19.7 per cent of the men) and money from other household members (14.6 per cent of the women and 11.2 per cent of the men). The rest (25.6 per cent of women and 20.8 per cent of men) have other kinds of income including earnings from own business, state grants (old-age pension, child support, disability, foster care), and remittances from people outside the household. Regarding the marital status of South Africans, 64.5 per cent of the single population is poor people while among married or cohabiting people poor people correspond to 52.9 per cent. 
Turning to the data on time use, Table 4 presents summary statistics on time use patterns of poor and non-poor women and men. The activity categories used in the table are as follows. Paid work activities involve employment for establishments (wage employment, home-based work for an establishment, etc.) as well as primary production activities not for establishments (such as crop farming, hunting, and fishing). Unpaid work category consists of water and fuel collection, social care (care for children, the sick, elderly and disabled for own household plus community services and help to other households) and home maintenance (household maintenance, management and shopping for own household). Non-work activities involve learning, social and cultural activities, mass media use (such as reading, watching television and video), sleep, necessary care (personal care and self-maintenance such as eating, drinking and receiving medical care) and unclassified activities.

Table 4: Hours spent on paid work, unpaid work and non-work in a day

\begin{tabular}{llcccc|cccc}
\hline & \multicolumn{3}{c|}{ NON-POOR $^{*}$} & \multicolumn{4}{c}{ POOR } \\
\hline \multirow{5}{*}{ Women } & Mean & S.D.* & Min & Max & Mean & S.D. $^{*}$ & Min & Max \\
& Paid Work & 3.3 & 4.3 & 0 & 20.4 & 1.9 & 3.5 & 0 & 20 \\
& Unpaid Work & 3.7 & 2.9 & 0 & 14.3 & 4.7 & 3.1 & 0 & 17 \\
& Water and Fuel Col. & 0 & 0.3 & 0 & 6 & 0.2 & 0.7 & 0 & 8.5 \\
& Social Care & 0.6 & 1.4 & 0 & 10 & 0.8 & 1.6 & 0 & 14 \\
& Home Maintenance & 3.1 & 2.4 & 0 & 14.3 & 3.7 & 2.5 & 0 & 13 \\
& Non Work & 16.9 & 3.8 & 3.6 & 24 & 17.4 & 3.7 & 4 & 24 \\
\hline \multirow{5}{*}{ Men } & Paid Work & 5.6 & 4.8 & 0 & 19.5 & 3.9 & 4.6 & 0 & 20.1 \\
& Unpaid Work & 1.5 & 1.9 & 0 & 11.8 & 1.6 & 2 & 0 & 14.5 \\
& Water and Fuel Col. & 0 & 0.3 & 0 & 8.5 & 0.1 & 0.4 & 0 & 6.5 \\
& Social Care & 0.1 & 0.7 & 0 & 10.4 & 0.1 & 0.7 & 0 & 9.3 \\
& Home Maintenance & 1.3 & 1.7 & 0 & 11.8 & 1.4 & 1.8 & 0 & 14.5 \\
& Non Work & 16.9 & 4.6 & 3 & 24 & 18.5 & 4.4 & 2.1 & 24 \\
\hline Source: Authors' calculation using TUS 2000. & & & & & & &
\end{tabular}

* Stance: Authors' calculat
Stand Deviation

Figures in Table 4 show that women and men spend between zero and approximately twenty hours of their day doing paid work activities. While 65.7 per cent of women reports zero hours of paid work time, the corresponding figure is 44.5 per cent for men. Paid work time is smaller for women and men in poor families than for their counterparts in non-poor families. On average, the numbers of hours spent doing paid work by women and men are 2.4 and 4.6 respectively. Contrary to paid work time, women spend more time for unpaid work then men do. Unpaid work time is highest among poor women, followed by non-poor women. Unpaid work time of non-poor and poor men are not very different from each other: 1.5 and 1.6 hours respectively. On average, hours spent for unpaid work is 4.4 for women and 1.5 hours for men. Hours spent on unpaid work by men peak at zero hours: 35 per cent of men reports zero hours of unpaid work. The figure for women is only 6.5 per cent. Time spent on non-work activities (learning, leisure, sleep and necessary care) is the same for women and men in non-poor families, averaging 16.9 hours for both. However, among the poor households non-work time of poor men is higher than for poor women: 18.5 and 17.4 hours per day, respectively. The descriptive statistics of Table 4 suggest that both women and men in poverty spend less time for paid work and more time on unpaid work activities. While women under poverty spend, on average, an extra hour per day compared to their non-poor counterparts, the corresponding figure is negligible at only around 6 minutes per day for men. 


\section{Methodology}

Many of the respondents in our dataset appear to spend zero time on specific activities. This is a common problem in the data provided by time use surveys. Besides the usual technical problems in data collection, there are two sources of zero observations in time use surveys (Flood \& Grasjö, 1998). Either individuals never participate in doing the work specified or, even though in general they do these activities, for some reason, they spend zero time on the day selected for the interviews. Data sets of this sort with truncation require specific methods (Wooldridge, 2009). Different estimation methods are introduced in the literature in order to solve the problem of a large number of respondents reporting zero time: the double-hurdle model, Heckman's model and Tobit model. Unlike the Tobit model, the Heckman and double-hurdle models consider the decision to participate in doing work as an independent process from the decision on the duration of market work. Modelling the participation decision process of doing unpaid work is not as straightforward as in the case of the labour supply model. Introducing a misspecified participation equation in the double-hurdle or Heckman's model can produce worse results than implementing a Tobit model (Flood \& Grasjö, 1998). Therefore, in this study, we select the Tobit model for our estimations; that is, we treat zero observations as individuals' desired amount of unpaid and paid work. The empirical specification we use is:

$$
y_{j, i}=\beta_{j}^{\prime} x_{i}+\epsilon_{j, i}
$$

where $y_{j, i}$ is the latent variable representing the time (in minutes) allocated to activity $j$ by individual $i, x_{i}$ is a vector of explanatory variables, $\beta_{j}$ is a vector of parameters and $\epsilon_{j, i}$ is the error term. The observed time allocation $\left(y_{j, i}\right)$ variables are related to the corresponding latent time allocation variables by

$$
y_{j, i}= \begin{cases}y_{j, i}^{*}, & \text { if } y_{j, i}>0 . \\ 0, & \text { if } y_{j, i} \leq 0 .\end{cases}
$$

We also take into account the fact that time use in different activities is determined simultaneously (i.e. that the unobserved factor that influences time use of different activities might be correlated). Thus the specification we use is a multivariate Tobit. ${ }^{9}$ This method provides statistical efficiency gains by using the full information about the error correlation. Apart from the estimation efficiency, the multivariate specification allows one to analyze the correlations between the error terms of the equations that reflect the correlations between time allocations among different activities not accounted for by the explanatory variables.

In what follows, we first present the results obtained by estimating a bivariate Tobit model where the dependent variables are paid and unpaid work. Bivariate analysis of time

\footnotetext{
${ }^{9}$ Recently researchers are considering OLS regressions rather than Tobit estimations in time use analyses. Proponents of OLS regressions argue that the zeros we observe in time diaries do not necessarily mean that the individual does not perform the activity. It may be a mismeasurement because the individual did not participate in the activity just on the diary day (Steward, 2009). Thus, the zeros in time-use data, according to this view, arise from a discrepancy between the period of the diary day (one day) and the period of interest which is generally longer. A recent study by Foster \& Kalenkoski (2013) provides evidence on this problem by making estimations using 24 -hour and 48-hour periods of time use data. Their results imply that a substantial part of the zeros in a one-day observation period is real and reflect censoring rather than mismeasurement. Thus, Tobit is more appropriate than OLS estimation in this case.
} 
use considers different unpaid work activities in one basket. However, according to Gronau (1973), different time use activities can only be combined into composite measures if each responds similarly to various socioeconomic factors. Kimmel \& Connelly (2006) shows specifically that time spent on social care responds in a unique way to various explanatory variables. They conclude social care must be modelled as distinct from household maintenance. Thus, we next disaggregate the time spent on unpaid work into different housework categories and implement a multivariate Tobit model. The time-use categories in this specification are paid work $(j=p)$, water and fuel collection $(j=w)$, social care $(j=s)$ and home maintenance $(j=m)$. The difficulty in estimating this model is in the evaluation of the four-dimensional multivariate normal integral (Amemiya, 1974).

As a solution to this problem, a number of methods have been proposed in the literature that rely either on restrictive assumptions about the model structure and the disturbances or on numerical methods that are costly in terms of computing time (Hajivassiliou \& Ruud, 1994; Stern, 1997; Arias \& Cox, 2001). An alternative method that outperforms these in terms of computing time and accuracy is the maximum simulated likelihood (MSL). This method consists of evaluation of the integrals in the log-likelihood function by simulation rather than calculation. ${ }^{10}$ Reviewing several probability simulators using Monte Carlo methods, Hajivassiliou et al. (1996) found that the Geweke-Hajivassiliou-Keane (GHK) simulator performed better than other simulators in terms of robustness and accuracy. ${ }^{11}$ Based on these ongoing discussions in the literature, we employ in this paper the MSL method using the GHK simulator to estimate the model in equations (1) and (2).

Turning to the explanatory variables controlled in our estimations, xi includes both the household and individual characteristics in addition to the poverty status of the household (poor standing for being poor). Our household characteristics controls are as follows: the residential location of the household $\left(u r b_{f}, u r b_{i}\right.$, and rur $_{c}$ representing formal urban, informal urban, and rural commercial areas respectively), the number of children by sex and age (0-6 age group (chil-y) children and the girls and boys in the 7-18 age group (chil-o-g and chil $-O-b$, respectively) $)^{12}$, the number of adults (female and male adults in the 19-65 age group (adult- $f$ and adult-m)) and the number of elder members at age 66 and over (old). ${ }^{13}$

We expect, being employed ${ }^{14}$, being married and having a higher number of school years to have a negative impact on unpaid work time and the reverse impact on paid work time.

\footnotetext{
10 See Hajivassiliou \& Ruud (1994) for alternative estimation methods that rely on simulation.

11 The simulation methods use the fact that the integrals of interest correspond to the probability of an even in a population. The GHK simulator, in turn, approximates these probabilities by taking a number of random draws from the truncated standard normal distribution and taking the average of the simulated probabilities. See Hajivassiliou \& Ruud (1994), Stern (1997), Arias \& Cox (2001), and Greene (2008), among others, for an explanation of the GHK simulator.

12 chil $-y$ stands for young children i.e. children between ages 0 and 6 . chil $-o-g$ and chil $-o-b$ stand for older children (between ages 7 and 18) who are girls and boys respectively.

13 Two other exogenous variables, wage of the individual and income of the other household members, should ideally be included in the equation. However, this could not be done here due to the lack of continuous and consistent income variables in the dataset.

14 The paid work activities include 'short breaks and interruptions from work' and 'seeking employment and related activities'. Thus time for paid work is not necessarily zero for those not employed.
} 


\section{Estimation Results}

Bivariate Tobit estimation results are presented in Table 5. The specification of the model is jointly highly significant for estimations for both women and men: The $\chi^{2}$ statistics of $1,801.66$ and $1,130.89$, respectively, indicate rejection of the null hypothesis that all slope coefficients are zero at the $1 \%$ level. The null hypothesis of independence of time use in different activities is also rejected as the correlation of errors $(-0.45$ and -0.36 for the estimations for women and men respectively) are significant at one per cent level, indicating that individuals allocate their time to different activities concurrently rather than independently. Estimation results for the multivariate Tobit specification are presented in Table 6 . It is observed that the specification of this model is also jointly highly significant in both estimations. As in the bivariate model, the likelihood ratio test for the independence of time allocations implies that time allocation to different activities that are not explained by the explanatory variables are correlated. In what follows, we jointly analyse the coefficients obtained from the bivariate and multivariate estimations.

Estimation results show first that being poor is related negatively to both women's and men's time spent on paid work time. This result is expected as the conditions of the poverty limit the access to regular full-time job opportunities. ${ }^{15}$ An argument in the literature on the domestic appliances in the household, which serve as labour-saving technology puts that they spare time on paid work or looking for work while decreasing required unpaid work time. The marginal effect of being poor on paid work time of women and men are calculated as -29.84 and -47.15 respectively for the bivariate specification and -30.39 and -48.10 respectively for the multivariate specification. ${ }^{16}$ These results indicate that poor women spend approximately thirty minutes less time on paid work compared to non-poor women. The difference for men is forty-seven-forty-eight minutes.

Unlike the association between poverty and paid work on the same direction, the correlation of poverty with women's and men's unpaid work time is asymmetrical: women living under poverty spend more time on unpaid work activities whereas men's unpaid work time does not show any significant change. The difference between unpaid work time of poor women and that of non-poor women is 37.7 minutes according to the bivariate specification. Another interesting fact that emerges out of these estimations is that the increase in women's unpaid work time under poverty is higher than the decrease in their paid work time. Thus poor women work more in total compared to non-poor women.

\footnotetext{
15 There is a potential endogeneity issue given the two-way relationship between poverty and time use. We use a household poverty status variable directly in estimating time spent on paid and unpaid work activities by household members. Here, we assume that the poverty status of the household is affected directly by the total contribution of paid work time of its members. While the poverty status is a household variable, the dependent paid work time variable is an individual variable in our data set. Thus if there is an influence from paid work to poverty, it would possibly be a weak one. Secondly, the respondents are not exclusively household heads (male or female) whose paid work time could be more directly linked with the poverty status of the household. Respondent members include children or other members. Nevertheless, due to the possibility of endogeneity problem, we are cautious in interpreting the estimated coefficients, and treat them as reflecting controlled associations between the dependent and the independent variables, rather than causal relations.

16 The tables report the estimated coefficients. Marginal effects can be found by multiplying the estimated coefficients with the scaling factor, which is approximated here with the proportion of uncensored observations. The scaling factors are reported in Table 5 and 6 .
} 
Table 5: Bivariate Tobit estimation results for time use of women and men

\begin{tabular}{|c|c|c|c|c|c|}
\hline & & \multicolumn{2}{|c|}{ Women } & \multicolumn{2}{|c|}{ Men } \\
\hline & & Paid & Unpaid & Paid & Unpaid \\
\hline \multirow[t]{11}{*}{ Constant } & & $-675.37^{* *}$ & 10.64 & $-709.28^{* *}$ & $64.64^{*}$ \\
\hline & & -93.85 & -35.62 & -90.76 & -35.02 \\
\hline & poor & $-80.21^{* *}$ & $39.25^{* *}$ & $-81.97 * *$ & 7.74 \\
\hline & & -21.66 & -8.56 & -19.82 & -8.43 \\
\hline & $u r b_{-} f$ & -23.05 & $-59.77 * *$ & -8.55 & $-34.37 * *$ \\
\hline & & -23.86 & -9.04 & -25.03 & -9.61 \\
\hline & $u r b_{-} i$ & -31.82 & $-20.77^{*}$ & 23.93 & -3.62 \\
\hline & & -27.6 & -10.71 & -27.06 & -10.27 \\
\hline & $r u r_{-} c$ & $50.75^{*}$ & $-24.29 * *$ & $106.46^{* *}$ & $-24.27^{* *}$ \\
\hline & & -27.73 & -11.49 & -24.86 & -10.23 \\
\hline & chil-y & -5.89 & $39.90^{* *}$ & $29.72^{* *}$ & -2.46 \\
\hline Household & & -11.29 & -4.68 & -12.61 & -5.33 \\
\hline \multirow[t]{14}{*}{ Characteristics } & chil-o-g & -11.48 & $-10.63^{* *}$ & -8.54 & 7.55 \\
\hline & & -10.88 & -4.33 & -15.6 & -5.71 \\
\hline & chil-o- $b$ & -2.42 & 6.02 & -9.05 & 2.28 \\
\hline & & -13.63 & -5.07 & -13.17 & -5.22 \\
\hline & adult- $f$ & 8.49 & $-24.00 * *$ & -4.98 & $-24.9^{* *}$ \\
\hline & & -11.39 & -4.26 & -12.81 & -4.59 \\
\hline & adult-m & $-27.04^{* *}$ & 5.78 & 3.35 & 1.47 \\
\hline & & -13.77 & -7.53 & -11.52 & -3.79 \\
\hline & old & 10.58 & 8.26 & 20.28 & -3.99 \\
\hline & & -19.38 & -6.78 & -20.26 & -6.87 \\
\hline & $e m p$ & $525.93^{* *}$ & $-89.31^{* *}$ & $407.09^{* *}$ & $-37.87^{* *}$ \\
\hline & & -21.14 & -9.33 & -25.59 & -9.85 \\
\hline & married & -7.71 & $39.11^{* *}$ & $71.47^{* *}$ & $-36.07 * *$ \\
\hline & & -20.9 & -8.16 & -24.09 & -10.52 \\
\hline Individual & age & $17.28^{* *}$ & $15.5^{* *}$ & $32.63^{* *}$ & $3.31^{*}$ \\
\hline \multirow{5}{*}{ Characteristics } & & -4.85 & -1.94 & -4.82 & -1.93 \\
\hline & $a g e^{2}$ & $-0.18^{* *}$ & $-0.19 * *$ & $-0.4^{* *}$ & -0.03 \\
\hline & & -0.06 & -0.02 & -0.06 & -0.02 \\
\hline & school & 2.68 & 1.87 & -3.75 & 0.98 \\
\hline & & -2.91 & -1.25 & -2.95 & -1.12 \\
\hline \multicolumn{2}{|l|}{ corr. of errors } & $-0.45^{* *}$ & & $-0.36^{* *}$ & \\
\hline & & -0.02 & & -0.02 & \\
\hline \multicolumn{2}{|l|}{$N$} & 6,000 & & 5,228 & \\
\hline & 0.38 & 0.96 & 0.58 & 0.75 \\
\hline \multirow{2}{*}{\multicolumn{2}{|c|}{$\begin{array}{l}H_{0}: \beta_{i}=0 \\
\chi^{2}(30)\end{array}$}} & & & & \\
\hline & & 1801.66 & & 1130.89 & \\
\hline \multirow{2}{*}{\multicolumn{6}{|c|}{$\begin{array}{l}\text { Note: The dependent variables are paid work (Paid), unpaid work (Unpaid). Robust standard } \\
\text { errors in parentheses, where }{ }^{*} \text { significant at } 10 \%,{ }^{* *} \text { significant at } 5 \% \text { level. } \\
\dagger \text { Scaling factor for the marginal effects. }\end{array}$}} \\
\hline & & & & & \\
\hline \multicolumn{6}{|c|}{$\begin{array}{l}\text { The variable definitions are as follows: poor is the dummy variable indicating poor house- } \\
\text { holds, urb-f, urb_ } i \text { and rur } r \text { are dummies indicating formal urban, informal urban and rural } \\
\text { commercial areas; chil }-y, y \text {, chil }-o-g \text { and chil }-o-b \text { are the number of children in the } 0-6 \\
\text { age group, in the } 7-18 \text { age group-girls and in the } 7-18 \text { age group-boys; adult }-f, \text { adult }-m \\
\text { and old are the number of adults -female, of adults -male and of elder members at age } 66 \\
\text { and over; emp and married are dummy variables indicating if the person is employed and } \\
\text { if the person is married or cohabiting with a partner; age, age } 2 \text { and school are age and the } \\
\text { square of age of the person and the number of years of schooling respectively. }\end{array}$} \\
\hline
\end{tabular}

The multivariate estimation results are similar to the bivariate ones. In addition, these estimations reveal that the increase in poor women's unpaid work time rises due to a rise in time spent on home maintenance (37.83 minutes) as well as water and fuel collection (7.72 minutes). ${ }^{17}$ These finding altogether signifies the unequal burden of poverty in terms of unpaid work time borne by women.

\footnotetext{
17 The coefficient of the poor dummy on the home maintenance time of men is found to be positive and statistically significant, although only at the ten per cent level. The marginal effect of this variable is very small compared to that of women: 10.12 minutes.
} 
Table 6: Multivariate Tobit estimation results for time use of women and men

\begin{tabular}{|c|c|c|c|c|c|c|c|c|}
\hline \multirow{4}{*}{ Constant } & \multicolumn{4}{|c|}{ Women } & \multicolumn{4}{|c|}{ Men } \\
\hline & Paid & Care & Home & Water & Paid & Care & Home & Water \\
\hline & $-679.76^{* *}$ & $-289.14^{* *}$ & -12.13 & -62.32 & $-711.51^{* *}$ & $-586.19 * *$ & $65.1 * *$ & -34.98 \\
\hline & -95.16 & -37.63 & -29.86 & -44.5 & -90.65 & -105 & -31.48 & -73.26 \\
\hline \multicolumn{9}{|c|}{ Household Characteristics } \\
\hline \multirow[t]{2}{*}{ poor } & $-81.7^{* *}$ & 8.6 & $39.84^{* *}$ & $60.27^{* *}$ & $-83.63^{* *}$ & -18 & $14.03 *$ & 12.92 \\
\hline & -21.88 & -8.38 & -7.48 & -15 & -19.72 & -19 & -7.56 & -20.13 \\
\hline \multirow[t]{2}{*}{$u r b_{-} f$} & -20.77 & 5.99 & $-38.51^{* *}$ & $-201.23^{* *}$ & -10.3 & 11.4 & $-18.99 * *$ & $-165.79^{* *}$ \\
\hline & -24.21 & -9.3 & -7.62 & -15.32 & -25.13 & -23 & -9.22 & -29.57 \\
\hline \multirow[t]{2}{*}{$u r b \_i$} & -26.48 & 10.19 & -2.72 & $-102.38^{* *}$ & 23.12 & 17.1 & 5.79 & $-58.51^{* *}$ \\
\hline & -27.81 & -10.84 & -9.05 & -11.42 & -27 & -27 & -9.94 & -16.32 \\
\hline \multirow[t]{2}{*}{ rur_c } & $56.19^{* *}$ & 2.69 & -8.51 & $-56.46^{* *}$ & $105.55^{* *}$ & -23 & -15.61 & -12.87 \\
\hline & -27.91 & -11.06 & -9.57 & -12.38 & -24.83 & -27 & -9.92 & -15.23 \\
\hline \multirow[t]{2}{*}{ chil-y } & 0.22 & $91.92^{* *}$ & 0.86 & 6.7 & $29.79 * *$ & $22.48^{* *}$ & -7.88 & 13.05 \\
\hline & -10.96 & -4.95 & -3.56 & -6.27 & -12.6 & -10 & -5.44 & -9.43 \\
\hline \multirow[t]{2}{*}{ chil-o-g } & -12.2 & -0.97 & $-7.54^{* *}$ & -4.92 & -7.46 & $32.47^{* *}$ & 0.38 & 11.7 \\
\hline & -11 & -4.14 & -3.64 & -5.37 & -15.22 & -13 & -5.45 & -12.42 \\
\hline \multirow[t]{2}{*}{ chil-o-b } & -2.18 & 0.79 & 4.82 & 8.79 & -9.74 & $29.33^{* *}$ & 0.38 & $-18.68^{*}$ \\
\hline & -13.91 & -4.39 & -4.33 & -5.49 & -13.04 & -12 & -4.64 & -10.17 \\
\hline \multirow[t]{2}{*}{ adult- $f$} & 7.62 & $-29.65^{* *}$ & $-15.48^{* *}$ & 2.95 & -4.97 & -18 & $-21.08 * *$ & -5.06 \\
\hline & -11.57 & -4.82 & -3.6 & -5.39 & -12.76 & -13 & -4.42 & -8.75 \\
\hline \multirow[t]{2}{*}{ adult-m } & $-26.35^{*}$ & -6.32 & $11.44^{*}$ & $-13.85^{* *}$ & 3.43 & -3.5 & 0.28 & -6.65 \\
\hline & -14 & -6.04 & -6.07 & -6.42 & -11.4 & -11 & -3.39 & -6.26 \\
\hline \multirow[t]{2}{*}{ old } & 10.49 & 5.63 & 6.48 & -11.86 & 20.35 & 23.5 & -7.45 & -7.21 \\
\hline & -19.41 & -7.89 & -6.13 & -10.03 & -20.23 & -17 & -6.17 & -14.87 \\
\hline \multicolumn{9}{|c|}{ Individual Characteristics } \\
\hline \multirow[t]{2}{*}{$e m p$} & $530.85^{* *}$ & $-23.9^{* *}$ & $-75.4^{* *}$ & $-33.88^{* *}$ & $406.92^{* *}$ & -9.4 & $-32.02 * *$ & $-44.47 * *$ \\
\hline & -21.41 & -8.21 & -7.82 & -10.57 & -25.47 & -22 & -8.94 & -19.23 \\
\hline \multirow[t]{2}{*}{ married } & -9.42 & $38.34^{* *}$ & $22.99 * *$ & 8.33 & $70.69^{* *}$ & $81.23^{* *}$ & $-40.28 * *$ & $-59.36^{* *}$ \\
\hline & -21.04 & -8.81 & -7 & -11.69 & -24.03 & -24 & -10.48 & -21.13 \\
\hline \multirow[t]{2}{*}{ age } & $17.2^{* *}$ & $9.54^{* *}$ & $12.38^{* *}$ & 2.85 & $32.76^{* *}$ & 4.84 & 2.75 & -2.06 \\
\hline & -4.94 & -1.98 & -1.65 & -2.32 & -4.8 & -4.7 & -1.74 & -3.95 \\
\hline \multirow[t]{2}{*}{ age2 } & $-0.18^{* *}$ & $-0.12^{* *}$ & $-0.14^{* *}$ & $-0.06 *$ & $-0.41^{* *}$ & -0 & -0.02 & 0.02 \\
\hline & -0.06 & -0.03 & -0.02 & -0.03 & -0.06 & -0.1 & -0.02 & -0.05 \\
\hline \multirow[t]{2}{*}{ school } & 2.51 & $4.83^{* *}$ & $2.59^{* *}$ & $-9.78^{* *}$ & -3.69 & $13.06^{* *}$ & -0.22 & $-5.73^{* *}$ \\
\hline & -2.94 & -1.21 & -1.04 & -1.63 & -2.92 & -3.8 & -1.01 & -2.46 \\
\hline \multicolumn{9}{|c|}{ Correlation of cross-equation error terms } \\
\hline Care & $-0.17^{* *}$ & & & & & $-0.2^{* *}$ & & \\
\hline & -0.03 & & & & & -0 & & \\
\hline Home & $-0.45^{* *}$ & 0.1 & & & & $-0.33^{* *}$ & $0.07 * *$ & \\
\hline & -0.02 & -0. & & & & -0 & -0.03 & \\
\hline Water & -0.02 & -0. & & $0.13^{* *}$ & & $-0.11^{* *}$ & -0.08 & $0.08^{*}$ \\
\hline & -0.04 & -0. & & -0.03 & & -0.1 & -0.08 & -0.05 \\
\hline$N$ & 6,000 & & & & & 5,228 & & \\
\hline Scale $f .^{\dagger}$ & 0.38 & 0.37 & 0.95 & 0.13 & 0.58 & 0.09 & 0.72 & 0.06 \\
\hline$H_{0}: \beta_{j}=0$ & & & & & & & & \\
\hline$\chi^{2}(64)$ & $2,555.85$ & & & & $1,398.85$ & & & \\
\hline $\begin{array}{c}H_{0}: \text { indeper } \\
\chi^{2}(6)\end{array}$ & $\begin{array}{r}\text { ndence of } \\
9,100.15\end{array}$ & me spent a & each act & & $9,431.04$ & & & \\
\hline
\end{tabular}

Note: See Table 5 .

The estimated coefficients of the control variables confirm most of our expectations: Compared to those in ex-homeland areas, women and men living in formal-urban and rural-commercial areas spend less time on unpaid work mostly because less time is spent on home maintenance and water and fuel collection in these areas. ${ }^{18}$ This result is in line with

${ }^{18}$ We'd like to note that this difference between formal-urban areas and other areas may include the influence of paid domestic workers in the household, which is more widely observed in urban. The information on whether there is a paid domestic worker in the household or not cannot properly be sorted from the available dataset. Unless at least one among the two selected members in the household reported that she/he is a 
earlier evidence that suggests that peoples' engagement with unpaid work is quite varied with respect to residential settlements. This is particularly true for developing country cases where there are households that have to collect their water and fuel activities that are drudgery and highly time-consuming (Charmes, 2006; Antonopoulos, 2008). In addition to these, time spent on home maintenance varies depending on the existence of time-saving home appliances as well as on the access to public resources such as electricity as a prerequisite for holding such home appliances. Compared to ex-homeland areas, which are underserved areas in terms of public investment, the probability of owning labour saving home appliances is much higher in urban areas. We also observe a significant and positive impact of living in rural-commercial areas on women's and men's paid work time: People living in ex-homeland areas spend less time on paid work compared to residents in rural-commercial areas.

The number of children between ages zero and six affects women and men differently. While for women, unpaid work time rises with the number of preschool children, for men, it is their paid work time that increases. Although total unpaid work time spent by men does not seem to be influenced by the number of preschool children, multivariate estimation results show that their allocation of unpaid work time among different activities change. Men do spend more time on care work activities though their overall unpaid work time does not increase.

When the number of children between ages seven and eighteen is considered, our findings are in line with previous findings that indicate that children allocate significant amounts of time to household maintenance as well as care of younger siblings helping their parents (Ilahi, 2000), we again observe sex-specific impacts. As the number of girls increases, women's unpaid work time decreases but the number of boys does not influence time use of women or men. For men, similar to younger children, older boys and girls do not lead to an increase in the overall unpaid work time of men, but they do influence their care work time positively. In addition, older boys lead to a decline in men's time spent collecting water and fuel. These results imply that women usually share their unpaid work burden with girls rather than the boys and men share their work burden with boys.

Similarly, the number of adults appears to have a different impact depending on gender and age. While the number of females who are in the nineteen to sixty-five age group significantly decreases both women's and men's time spent on unpaid work, the number of male adults in the same age group decreases only women's time spent on paid work. The number of adults older than age 65, on the other hand, does not have any significant impact. ${ }^{19}$ In addition, the results obtained from the multivariate analyses reveal that women in the nineteen-sixty-five age group help other women and men in caring and home maintenance activities while men at the same age group help women in collecting water and fuel.

paid domestic worker, gardener or a security guard we do not have the time use information for domestic workers in the household. If this is reported by the selected person that could mean she/he is working for pay in another household or that could mean she works in the same household. There is no separate question asked about this for every household in the sample. Thus we were not able to tease out the impact of domestic paid labourer's contribution.

19 This is true for both the number of elderly women and elderly men. As they have found to have similar effects, we have included them as one variable (old). 
Turning to individual characteristics, being married or cohabiting with a partner increases women's time for unpaid work, mainly through an increase in caring and home maintenance activities (14.2 and 21.8 minutes respectively). On the other hand, marriage increases men's time for paid work while decreasing their unpaid work time. The decrease in the unpaid work time of men results from a decrease in time spent on home maintenance (29 minutes) and on water and fuel collection (3.56 minutes), while time spent on caring activities increases to some extent (7.3 minutes) with marriage confirming the traditional division of work at home. This result is in line with our expectations and previous evidence that demonstrates that while married women do more housework than single women, men do less housework after they get married (Gupta, 1999; Couprie, 2007; Öneş et al., 2013). Both women's and men's paid work time increases with age but at a decreasing rate. The same result applies for unpaid work time of women.

Unexpectedly, we find that the number of years of schooling has no impact on paid work time spent by South African women and men. Social care work time of women and men, on the other hand, increases with the number of years of schooling. The positive and significant impact of the years of schooling on men's time spent on caring activities supports earlier findings provided by Huber \& Spitze (1983) that better-educated men spend more time on unpaid work activities. Schooling also has a significant and positive effect on only women's time for home maintenance. Finally, unlike other types of unpaid work time, we observe that the number of years of schooling has a significant negative impact on both women's and men's time spent on water and fuel collection, which might capture the positive relationship between the level of education and probability of having a job.

\section{Conclusion}

High-income poverty has been a major challenge in post-apartheid South Africa. In this study, using the time use data compiled in 2000 in South Africa we estimate the impact of poverty on South African women's and men's time use patterns. Using both bivariate and multivariate Tobit estimation methods, we present evidence for an unequal burden of poverty on time use patterns where the traditional division of labour is sharpened under poverty: poor women spend more time for unpaid work mostly for water and fuel collection as well as on home maintenance, whereas we do not observe any significant difference in poor and non-poor men's unpaid work time. This shows that unpaid work burden of poverty is not shared equally within a household. Time spent on paid work, on the other hand, decreases for poor households, more for men than that for women. Women's total work time (i.e., the total of paid and unpaid work time) increases with poverty as the increase in their unpaid work time extends away from the decline in paid work time.

Other results based on our econometric estimations are as follows. (1) Being married/cohabiting has a positive impact on women's unpaid work time by increasing the time they spend on caring and home maintenance activities. On the other hand, married/cohabiting men spend less time on home maintenance and fetching water and collecting fuel and more time on caring activities compared to their single counterparts. However, on average, being married/cohabiting with a partner has a positive impact on women's unpaid work whereas we observe the opposite for men's unpaid work time; (2) Number of preschool children raises women's unpaid work burden while increasing men's time spent on paid work; (3) Age has a determining positive impact on both women's and men's paid work but only on women's 
unpaid work time; (3) Better educated men spend more time on care activities as years of schooling increases men's time spent on social care. Years of schooling, on the other hand, increases their time for unpaid activities except for fetching water and collecting fuel. Time spent fetching water and collecting fuel decreases with education for both women and men.

Evidence obtained could be useful in designing anti-poverty policies sensitive to the unequal burden of poverty on men and women in South Africa. Our results reveal a hidden dimension of poverty, which is missing in the current anti-poverty agenda. Higher work burden of poor people due to longer hours of unpaid work time point to a double deficit they face: an income as well as a time deficit. Results indicate that income deficit cannot be the sole target in fighting poverty. While for some, higher-paying job opportunities would be adequate, for others compensation other than income would be needed. Any such intervention should also take into account the time availability of the target group. Public provisioning services that could decrease time burden due to long hours of unpaid work particularly performed by women could increase paid work participation of women and at the same time help fight with income poverty.

The current study is based on a one-year, cross-sectional time use information. Populationbased case-control studies repeated cross-sections; in other words, panel setting databases produces a more appropriate setting to explore both the temporal and causal effects. Nevertheless, time use diaries are in general collected in ten-year rounds. An overtime statistical matching implemented on a cross-sectional time use data with a panel income and living conditions database would work better to analyse our main research question, which is a task for our next research agenda.

\section{Acknowledgements}

The authors appreciate the editors' and the reviewers' comments and suggestions that helped improve the previous version of the paper. We are grateful to the session participants at the IATUR Annual Conference, Rania Antonopoulos and Hasan Şahin for guiding comments, insights and support. Needless to further mentioning, all remaining errors and views expressed remain as solely our responsibility. 


\section{References}

Aliber, M. (2003). Chronic Poverty in South Africa: Incidence, Causes and Policies. World Development, 31(3), 473-90. doi:10.1016/S0305-750X(02)00219-X

Amemiya, T. (1974). Multivariate Regression and Simultaneous Equation Models when Dependent Variables Are Truncated Normal. Econometrica, 42(6), 999-1012.

Antonopoulos, R. (2008). The Unpaid Care Work-Paid Work Connection (Working Paper No. 541). The Levy Institute.

Antonopoulos, R., \& Hirway, I. (2010). Unpaid Work and the Economy: Gender, Time Use and Poverty in Developing Countries. New York: Palgrave Macmillan.

Arias, C., \& Cox, T. L. (2001). Estimation of a US Diary Sector Model by Maximum Simulated Likelihood. Applied Economics, 33(9), 1201-11. doi:10.1080/00036840010005797

Armstrong, P., Lekezwa, B., \& Siebrits, K. (2008). Poverty in South Africa: A Profile Based On Recent Household Surveys (Working Paper No. 04/08). Stellenbosch University.

Becker, G. S. (1981). A Treatise on the Family. Boston: Harvard University Press.

Beneria, L. (2003). Gender, Development, and Globalization: Economics as if People Mattered. New York: Routledge.

Bittman, M., \& Folbre, N. (2004). Family Time: The Social Organization of Care. New York: Routledge.

Bittman, M., Folbre, N., England, P., Sayer, L., \& Matheson, G. (2003). When Does Gender Trump Money? Bargaining and Time in Household Work. American Journal of Sociology, $109(1)$, 186-214. doi:10.1086/378341

Bryan, M. L., \& Sevilla-Sanz, A. (2011). Does Housework Lower Wages? Evidence for Britain. Oxford Economic Papers, 63(1), 187-210. doi:10.1093/oep/gpq011

Burchardt, T. (2008). Time and Income Poverty (Report No. 57). Centre for Analysis of Social Exclusion (CASE), London School of Economics.

Cash, S. J., Sellers, S. L., \& Claps, M. (2005). Money Equals Time: Influence of Poverty Status on Hours Spent Doing Housework. Journal of Poverty, 9(2), 89-109. doi:10.1300/J134v09n02_05

Çağatay, N. (1998). Gender and Poverty (Working Paper No. 5). UNDP Social Development and Poverty Elimination Division.

Charmes, J. (2006). A Review of Empirical Evidence on Time Use in Africa from UN sponsored Surveys. In C. M. Blackden \& Q. Wodon (Eds.), Gender, Time Use, and Poverty in Sub-Saharan Africa (pp. 39-72). World Bank Working Paper No. 73. 
Connelly, R., DeGraff, D. S., \& Levison, D. (1996). Women's Employment and Child Care in Brazil. Economic Development and Cultural Change, 44(3), 619-56.

Couprie, H. (2007). Time Allocation within the Family: Welfare Implications of Life in a Couple. Economic Journal, 117(516), 287-305. doi:10.1111/j.1468-0297.2007.02012.x

Duncan, G. J., Dunifon, R. E., Doran, M. B. W., \& Yeung, W. J. (2001). How Different are Welfare and Working Families? And Do Those Differences Matter for Children's Achievement? In G. J. Duncan \& L. Chase-Lansdale (Eds.), For Better and for Worse: Welfare Reform and the Well-being of Children and Families (pp. 103-31). New York: Russell Sage.

Economic Commission for Latin America and the Caribbean (ECLAC). (2007). Women's Contribution to Equality in Latin America and the Caribbean. In 10th Session of the Regional Conference on Women in Latin America and the Caribbean.

Elson, D. (1993). Gender-aware Analysis and Development Economics. Journal of International Development, 5(2), 237-47. doi:10.1002/jid.3380050214

Elson, D. (2005). Unpaid Work: Creating Social Wealth or Subsidizing Patriarchy and Private Profit? [Lecture for the Forum on Social Wealth]. http://www. peri. umass . edu/ fileadmin/pdf/dpe/fsw/Diane.pdf.

Elson, D. (2009). Social Reproduction in the Global Crisis. In UNRISD Conference on Social and Political Dimensions of the Global Crisis, Palais des Nations, Geneva.

Esquivel, V. (2010). Lessons from the Buenos Aires Time-Use Survey: A Methodological Assessment. In R. Antonopoulos \& I. Hirway (Eds.), Unpaid Work and the Economy: Gender, Time Use and Poverty in Developing Countries (pp. 181-214). New York: Palgrave Macmillan.

Flood, L., \& Grasjö, U. (1998). Regression Analysis and Time Use Data A Comparison of Microeconometric Approaches with Data from the Swedish Time Use Survey (HUS) (Working Paper No. 5). University of Gothenburg, Department of Economics.

Floro, M. S. (1995). Women's Well-being, Poverty, and Work Intensity. Feminist Economics, 1(3), 1-25. doi:10.1080/714042246

Foster, G., \& Kalenkoski, C. M. (2013). Tobit or OLS? An Empirical Evaluation Under Different Diary Window Lengths. Applied Economics, 45(20), 2994-3010. doi:10.1080/00036846.2012.690852

Gershuny, J. (2000). Changing Times: Work and Leisure in Postindustrial Society. Oxford and New York: Oxford University Press.

Greene, W. H. (2008). Econometric Analysis (6th ed.). New Jersey: Pearson Education.

Gronau, R. (1973). The Intra-family Allocation of Time: The Value of the Housewives' Time. The American Economic Review, 63(4), 634-51. 
Gupta, S. (1999). The Effects of Transitions in Marital Status on Men's Performance of Housework. Journal of Marriage and the Family, 61(3), 700-11. doi:10.2307/353571

Haddad, L., \& Kanbur, R. (1990). How Serious Is The Neglect Of Intra-Household Inequality? Economic Journal, 100(402), 866-81. doi:10.2307/2233663

Hajivassiliou, V. A., McFadden, D., \& Ruud, P. (1996). Simulation of Multivariate Normal Rectangle Probabilities and Their Derivatives: Theoretical and Computational Results. Journal of Econometrics, 72(1-2), 85-134. doi:10.1016/0304-4076(94)01716-6

Hajivassiliou, V. A., \& Ruud, P. (1994). Classical Estimation Methods for LDV Models Using Simulation. In R. Engle \& D. McFadden (Eds.), Handbook of Econometrics (IV ed., pp. 2383-2441). New York: Elsevier.

Harris, B. (1990). The Intrafamily Distribution of Hunger in South Asia. In J. Dreze \& A. K. Sen (Eds.), The Political Economy of Hunger, Entitlement and Well-Being (pp. 351-425). New York: Oxford University Press.

Hartmann, H. (1979). The Unhappy Marriage of Marxism and Feminism: Towards a More Progressive Union. Capital and Class, 3(2), 1-33.

Harvey, A. S., \& Mukhopadhyay, A. K. (2007). When Twenty-four Hours is not Enough: Time Poverty of Working Parents. Social Indicators Research, 82(1), 57-77. doi:10.1007/s11205-006-9002-5

Hersch, J., \& Stratton, L. S. (1997). Housework, Fixed Effects, and Wages of Married Workers. Journal of Human Resources, 32(2), 285-307. doi:10.2307/146216

Hirway, I. (2010). Understanding Poverty: Insights Emerging from Time Use of the Poor. In R. Antonopoulos \& I. Hirway (Eds.), Unpaid Work and the Economy (pp. 22-57). Palgrave Macmillan, London.

Hoogeveen, J. G., \& Özler, B. (2006). Poverty and Inequality in Post-Apartheid South Africa: 1995-2000. In H. Bhorat \& R. Kanbur (Eds.), Poverty and Policy in Post-Apertheid South Africa (pp. 59-94). Cape Town: HSRC Press.

Hook, J. (2010). Gender Inequality in the Welfare State: Task Segregation in Housework, 1965-2003. American Journal of Sociology, 111(5), 1480-1523. doi:10.1086/651384

Huber, J., \& Spitze, G. (1983). Sex Stratification: Children, Housework, and Jobs. New York: Academic Press.

Ilahi, N. (2000). The Intra-household Allocation of Time and Tasks: What Have We Learnt from the Empirical Literature? (Working Paper Series No. 13). The World Bank.

Kimmel, J., \& Connelly, R. (2006). Determinants of Mothers' Time Choices in the United States: Caregiving, Leisure, Home Production, and Paid Work (Discussion Paper No. 2058). IZA. 
Klasen, S. (1997). Poverty, Inequality and Deprivation in South Africa: An Analysis of the 1993 SALDRU Survey. Social Indicator Research, 41(1-3), 51-94. doi:10.1023/A:100689221

Leibbrandt, M., Poswell, L., Naidoo, P., \& Welch, M. (2006). Measuring Recent Changes in South African Inequality and Poverty using 1996 and 2001 Census Data. In H. Bhorat \& R. Kanbur (Eds.), Poverty and Policy in Post-Apertheid South Africa (pp. 95-142). Cape Town: HSRC Press.

Memiş, E., \& Antonopoulos, R. (2010). Poverty Unpaid Work, Poverty and Unemployment: A Gender Perspective from South Africa. In R. Antonopoulos \& I. Hirway (Eds.), Unpaid Work and the Economy: Gender, Time Use and Poverty in Developing Countries (pp. 76-111). New York: Palgrave Macmillan. doi:10.1057/9780230250

Milkman, R. (1976). Women's Work and Economic Crisis: Some Lessons of the Great Depression. Review of Radical Political Economics, 8(1), 71-97. doi:10.1177/048661347600800107

Öneş, U., Memiş, E., \& Kızılırmak, B. (2013). Poverty and Intra-household Distribution of Work Time in Turkey: Analysis and Some Policy Implications. Women's Studies International Forum, 41(1), 55-64. doi:10.1016/j.wsif.2013.01.004

Sen, A. (1984). Resources, Values and Development. Cambridge, MA: Harvard University Press.

Skoufias, E. (1993). Labour Market Opportunities and Interfamily Time Allocation in Rural Households in South Asia. Journal of Development Economics, 40(2), 277-310. doi:10.1016/0304-3878(93)90086-3

South African Regional Poverty Network (SARPN). (2004). Fact sheet: Poverty in south africa. https://sarpn.org/documents/d0000990/.

Stern, S. (1997). Simulation-Based Estimation. Journal of Economic Literature, 35(4), 2006-39.

Steward, J. (2009). Tobit or Not Tobit? (Discussion Paper No. 4588). IZA.

van der Berg, S., Burger, R., Burger, R., Louw, M., \& Yu, D. (2006). Trends in Poverty and Inequality since the Political Transition (Working Paper No. 06/104). University of Cape Town.

Vickery, C. (1977). The Time-Poor: A New Look at Poverty. Journal of Human Resources, 12(1), 27-48. doi:10.2307/145597

Woolard, I., \& Leibbrandt, M. (1999). Measuring Poverty in South Africa (Working Papers No. 99/33). Development Policy Research Unit, University of Cape Town.

Wooldridge, J. (2009). Introductory Econometrics: A Modern Approach. Florence, KY: South Western Cengage Learning. 